\title{
PROSES BERPIKIR SISWA SMA DALAM MENYUSUN BUKTI MATEMATIS
}

\section{(THINKING PROCESS OF SENIOR HIGH SCHOOL IN COMPILE MATHEMATICAL PROOF)}

\author{
Widya Fatmahayati ${ }^{1}$, M. Ikhsan ${ }^{2}$, Cut Morina Zubainur ${ }^{3}$ \\ 1) 2) 3) Jurusan Pendidikan Matematika,Universitas Syiah Kuala, \\ widya.fatma209@gmail.com
}

\begin{abstract}
Abstrak
Pembelajaran matematika memiliki tujuan diantaranya mengkomunikasikan gagasan, penalaran serta mampu menyusun bukti. Informasi tentang proses berpikir siswa dalam pembuktian dapat membantu guru untuk merancang pembelajaran yang sesuai dengan proses berpikir siswa. Penelitian ini bertujuan untuk mengidentifikasikan proses berpikir siswa dalam menyusun bukti matematis. Penelitian ini merupakan penelitian deskriptif kualitatif yang dilakukan di SMA LabSchool Unsyiah dengan subjek enam siswa kelas XI. Ada tiga tahapan proses berpikir siswa yang dilihat pada saat siswa menyusun bukti matematika yaitu fase masuk (entry phase), fase menyelesaikan (attack phase), dan fase review (review phase). Data dikumpulkan melalui tes tertulis dan wawancara. Hasil penelitian menunjukkan siswa yang melalui fase masuk (entry phase) sebanyak 66,67\%, fase menyelesaikan (attack phase) sebanyak 33,33\%, dan fase review (review phase) sebanyak 83,33\%.
\end{abstract}

Kata kunci: Proses Berpikir, Bukti Matematis

\begin{abstract}
Mathematical learning has a purpose including communicating ideas, reasoning and being able to compile evidence. Information about the student's proof ability can help the teacher to find out the student's weaknesses and can design learning that is appropriate to the student's thought process. This study aims to determine the ability of students to compile mathematical proofs and to identify students' thought processes in preparing mathematical proofs. This research is a qualitative descriptive study conducted at Unsyiah LabSchool High School with the subject of six students of class XI. There are three stages that are seen in students' thinking processes, namely the entry phase, the attack phase, and the review phase. Data collected through written tests, interviews and documentation. The results showed that the students' ability to compile mathematical proofs was classified as an intermediate criterion. While the students' thinking process shows that some of the students have passed the entry phase, the attack phase, and the review phase.
\end{abstract}

Keywords: Thinking Process, Mathematical Evidence. 


\section{PENDAHULUAN}

Kemampuan penalaran dan berargumentasi logis merupakan salah satu tujuan pembelajaran matematika (NCTM, 2000). Siswa perlu dilatih membuat konjektur dan memeriksa kebenaran dari konjektur tersebut. Siswa juga perlu dibekali dengan kemampuan mengembangkan dan mengevaluasi argumen dan pembuktian matematika. Seterusnya, siswa juga dapat memilih dan menggunakan bermacam-macam jenis penalaran dan metode pembuktian.

Pembelajaran tentang bukti matematis telah diterapkan pada siswa sekolah menengah di dalam kurikulum 2013 kelas XI peminatan. Siswa sekolah menengah sudah mampu berpikir secara abstrak menurut logika-logika tertentu. Siswa sudah dapat memberikan alasan dengan menggunakan lebih banyak simbol atau gagasan dalam cara berpikir (Piaget \& Inhelder, 2010).

Bukti matematis merupakan salah satu materi yang sulit bagi siswa. Pekerjaan memahami bukti bukanlah sesuatu yang menarik bagi siswa karena banyak menggunakan simbol dan pernyataan logika daripada berhadapan dengan angka-angka yang biasanya dianggap sebagai karakter matematika. Rata-rata kemampuan pembuktian matematis mahasiswa belum memuaskan (Kusnandi, 2008). Mahasiswa masih belum mampu menyusun bukti kebenaran suatu pernyataan secara matematis berdasarkan definisi, prinsip dan teorema (Lestari, 2015: 130; Oktaviyanthi, Herman \& Dahlan, 2018: 196). Mahasiswa mengalami kesulitan dalam melakukan pembuktian disebabkan pengalaman berkaitan pembuktian ketika di sekolah sangat terbatas (Moore, 1994: 255). Kenyataan ini mengindikasikan bahwa kemampuan pembuktian mahasiswa masih memprihatinkan dan belum memuaskan, padahal pembuktian telah diajarkan kepada siswa sejak mereka duduk di bangku sekolah menengah. Oleh karena pengalaman siswa di sekolah menengah atas dalam menyusun pembuktian berdampak pada kemampuan pembuktian ketika mengikuti kuliah di perguruan tinggi, maka kemampuan pembuktian siswa perlu mendapat perhatian. Diperlukan informasi untuk mengetahui proses berpikir siswa dalam menyusun bukti matematis. Informasi ini yang kemudian akan berguna bagi guru dalam proses mengajar bukti matematis di sekolah.

Terdapat enam kriteria bukti yaitu pengalaman perorangan, penerimaan yang berhak, penyelidikan contoh-contoh, kurangnya kontra contoh, pemanfaatan hasil dan argumen deduktif. Argumen deduktif merupakan metode yang paling valid dalam pembuktian matematika. Bukti deduktif terbagi dua yaitu bukti dengan argumen langsung dan bukti dengan argumen tak langsung. Bukti dengan argumen langsung meliputi modus ponen, transitivitas atau silogisme, modus tollen, teorema deduksi, kontrapositif, bukti dengan kasus, dan induksi matematika. Bukti dengan argumen tak langsung meliputi kontra contoh dan bukti dengan kontradiksi (Tambunan \& Murtadho, 1987: 8.7).

Dalam belajar matematika, siswa diarahkan untuk berpikir secara matematis. Berpikir matematis merupakan tujuan penting dari pendidikan dan sebagai aspek penting dalam belajar matematika (Katagiri, 2012). Kegiatan berpikir penting untuk dilakukan dan dibiasakan pada siswa. Proses berpikir yang terjadi saat menyusun bukti dapat memberi petunjuk yang lebih baik untuk mengetahui kesulitan siswa.

Berdasarkan beberapa penelitian dan hasil penelitin di atas maka yang membedakan penelitian ini dengan penelitian sebelumnya terletak pada subyek 
penelitian ini adalah siswa SMA dan peneliti menganalisis proses berpikir siswa dalam menyusun bukti matematis dengan memberikan tes serta wawancara mendalam guna mendapatkan informasi lebih luas.

\section{KAJIAN TEORI}

Berpikir adalah proses dinamis yang dapat dilukiskan menurut proses atau jalannya. Berpikir itu adalah meletakkan hubungan antara bagian-bagian pengetahuan kita yaitu segala sesuatu yang telah kita miliki, yang berupa pengertian-pengertian dan dalam batas tertentu juga tanggapan-tanggapan.

Proses berpikir merupakan urutan kejadian mental yang terjadi secara alamiah atau terencana dan sistematis pada konteks ruang, waktu dan media yang digunakan, serta menghasilkan suatu perubahan terhadap objek yang mempengaruhinya. Proses berpikir merupakan peristiwa mencampur, mencocokkan, menggabungkan, menukar, dan mengurutkan konsep-konsep, persepsi-persepsi dan pengalaman sebelumnya. Menurut Mason dkk (2010) proses berfikir memiliki tiga fase yaitu: fase masuk (entry phase), fase menyelesaikan (attack phase), dan fase review (review phase). Pada fase masuk antara lain dilakukan proses pengenalan masalah dan mendefinisikan masalah. Pada fase ini dilakukan upaya mengelompokkan dan mengenali masalah termasuk dalam bidang aljabar, geometri, teori bilangan, kombinatorika, atau campuran. Pada fase ini juga diperkenalkan simbol dan notasi-notasi.

Tabel.1 Indikator Proses Berpikir Siswa dalam Menyusun Bukti Matematis

\begin{tabular}{|l|l|l|}
\hline \multicolumn{1}{c|}{$\begin{array}{c}\text { Langkah Menyusun } \\
\text { Bukti }\end{array}$} & \multicolumn{1}{|c|}{ Proses Berpikir } & \multicolumn{1}{c|}{ Indikator } \\
\hline $\begin{array}{l}\text { Fase masuk : } \\
\text { Memahami dan } \\
\text { Mendiagnosis Masalah }\end{array}$ & Menerima informasi & $\begin{array}{l}\text { Membaca informasi yang ada } \\
\text { pada soal. }\end{array}$ \\
\cline { 2 - 3 } & Mengolah informasi & $\begin{array}{l}\text { Menentukan informasi yang } \\
\text { penting (hipotesis dan } \\
\text { konklusi) }\end{array}$ \\
\cline { 2 - 3 } & $\begin{array}{l}\text { Menyimpan } \\
\text { informasi }\end{array}$ & $\begin{array}{l}\text { Menyebutkan yang mana } \\
\text { yang hipotesis yang } \\
\text { diketahui) dan yang mana } \\
\text { konklusi ( yang ditanya) pada } \\
\text { soal }\end{array}$ \\
\cline { 2 - 3 } & Memanggil Kembali & $\begin{array}{l}\text { Menyebutkan jenis bukti } \\
\text { yang akan digunakan untuk } \\
\text { membuktikan hipotesis }\end{array}$ \\
\hline $\begin{array}{l}\text { Fase menyelesaikan : } \\
\text { Menciptakan Solusi }\end{array}$ & Mengolah informasi & $\begin{array}{l}\text { Menentukan langkah operasi } \\
\text { matematika }\end{array}$ \\
\hline
\end{tabular}




\begin{tabular}{|c|c|c|}
\hline & $\begin{array}{l}\text { Menyimpan } \\
\text { informasi }\end{array}$ & $\begin{array}{l}\text { Menggunakan hasil dari } \\
\text { setiap langkah sebelumnya } \\
\text { untuk menentukan hasil akhir }\end{array}$ \\
\hline & Memanggil Kembali & $\begin{array}{l}\text { Melaksanakan langkah } \\
\text { operasi matematika serta } \\
\text { menyatakan alasan pada } \\
\text { setiap langkahnya }\end{array}$ \\
\hline \multirow[t]{3}{*}{$\begin{array}{l}\text { Fase review : } \\
\text { Mengevaluasi Solusi }\end{array}$} & Mengolah informasi & $\begin{array}{l}\text { Mengaitkan inti permasalahan } \\
\text { di soal dengan penyelesaian } \\
\text { yang dilakukan. }\end{array}$ \\
\hline & $\begin{array}{l}\text { Menyimpan } \\
\text { informasi }\end{array}$ & $\begin{array}{l}\text { Memeriksa kembali langkah- } \\
\text { langkah yang telah dilakukan }\end{array}$ \\
\hline & Memanggil Kembali & $\begin{array}{l}\text { Menyatakan alasan apabila } \\
\text { terdapat perbedaan antara } \\
\text { hasil sebelum dan sesudah } \\
\text { pengecekan }\end{array}$ \\
\hline
\end{tabular}

Fase masuk, pada tahap ini yang diamati adalah siswa mampu mengubah pernyataan kedalam kalimat implikatif dengan menunjukkan hipotesis yang mana dan konklusi yang mana dengan kalimatnya sendiri. Selanjutnya siswa mampu menentukan jenis bukti yang tepat dalam menentukan konklusi pada soal. Fase menyelesaikan, pada tahap ini yang diamati adalah siswa mampu melakukan langkah operasi matematika dengan tepat, siswa mampu memberikan alasan yang tepat dari jawaban yang ditulisnya. Fase review, yang diamati adalah siswa mampu menunjukkan konklusi benar dan mampu membuat simpulan dengan tepat serta melakukan evaluasi terhadap hasil pekerjaannya.

\section{METODE}

Metode yang digunakan dalam penelitian ini merupakan metode pendekatan kualitatif. Penelitian kualitatif dilaksanakan untuk mencapai tujuan penelitian yaitu mengetahui proses berpikir siswa dalam menyusun bukti matematis. Penelitian kualitatif digunakan untuk menemukan data empiris dalam rangka memahami proses berpikir siswa dalam menyusun bukti matematis. Menurut Strauss \& Corbin (1997), penelitian kualitatif merupakan salah satu pendekatan penelitian yang menghasilkan data berupa kata-kata tertulis atau lisan dari orang-orang dan perilaku yang dapat diamati secara langsung sesuai apa adanya.

\section{Partisipan}


Subjek penelitian ini adalah siswa Kelas XI di Labschool Unsyiah Banda Aceh berjumlah 31 siswa. Kemudian peneliti mewawancarai sebanyak 6 subjek, dimana subjek dipilih berdasarkan hasil jawaban siswa yang menjawab setiap soal tes yang diberikan, memiliki jawaban berbeda dengan subjek lainnya untuk setiap soalnya, melakukan kesalahan pada soal tes yang diberikan untuk setiap soalnya. Instrumen penelitian berupa tes kemampuan bukti matematis dan pedoman wawancara. Soal tes terdiri dari lima butir soal, yang terdiri dari jenis bukti informal, bukti induksi matematika, bukti langsung modus ponen dan tollen serta bukti tak langsung kontradiksi.

\section{Pengumpulan Data}

Data dalam penelitian ini diperoleh dengan menggunakan beberapa teknik pengumpulan data yaitu melalui tes tertulis dan wawancara. Tes tertulis peneliti diberikan kepada siswa setelah dilakukan perbaikan berdasarkan saran dari validator. Dalam menjawab siswa tidak diperkenankan membuka buku, dan waktu dalam menjawab soal adalah 90 menit. Melalui tes tertulis peneliti menganalisis hasil jawaban siswa. Dalam penelitian ini teknik wawancara yang dilakukan peneliti adalah jenis wawancara tidak terstruktur, namun memiliki aturan khusus.

\section{Analisis Data}

Analisis data menggunakan deskriptif kualitatif. Analisis deskriptif kualitatif adalah pengelolaan data dalam bentuk kata-kata bukan berupa data statistik. Model analisis data dalam penelitian ini mengikuti konsep yang diberikan Miles dkk. (2014), yang mengungkapkan bahwa aktifitas dalam analisis data kualitatif dilakukan secara interaktif dan berlangsung secara terus-menerus pada setiap tahapan penelitian .

\section{HASIL DAN PEMBAHASAN}

Proses berpikir siswa dalam menyusun bukti matematis dapat dilihat berdasarkan jawaban siswa dari tes yang diberikan serta jawaban siswa pada saat wawancara. Proses berpikir siswa dalam menyusun bukti matematis yang dilihat yaitu entry phase, attack phase, dan review phase. Berdasarkan kriteria penjaringan subjek peneliti memilih enam subjek yang telah mewakili dari krieria yang peneliti harapkan.

Berikut adalah hasil petikan tes dan wawancara yang dilakukan oleh subjek penelitian:

1. Subjek Penelitian 1

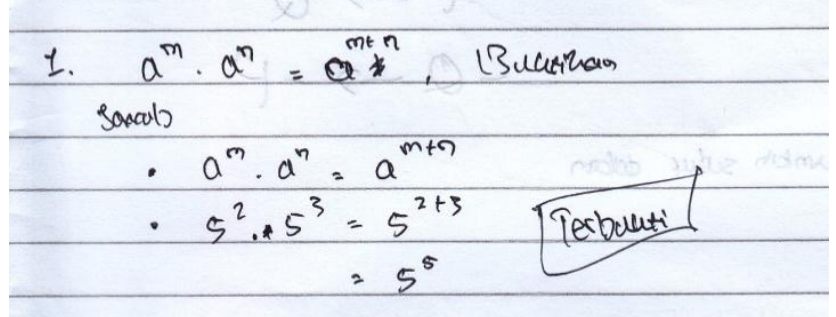

Gambar 1. Jawaban subjek 1

Pada Gambar. 1 terlihat bahwa siswa telah memahami maksud soal, 
ditandai dari jawaban siswa yang menggunakan bukti informal, namun masih menggunakan satu contoh saja.

Berikut hasil petikan wawancara peneliti dengan subjek :

Peneliti : Menurut kamu kalo kita mau buktiin sesuatu cukupkah dengan satu contoh saja?

Siswa : Tergantung ibu, kayaknya boleh-boleh aja.

Peneliti : Mengapa kamu ngebuktiinnya pake cara ini?

Siswa : Karena cara ini yang bisa buk.

Peneliti : Apakah kamu memeriksa kembali hasil pekerjaanmu?

Siswa : Hehe.. enggak buk.

Berdasarkan hasil tes dan wawancara di atas dapat disimpulkan bahwa siswa telah melalui tahapan proses berfikir dalam menyusun bukti matematika dengan baik.

2. Subjek Penelitian 2

\begin{tabular}{|c|c|}
\hline (2). & $1+3+5+7+\ldots+(2 n-1)=n^{2}$ \\
\hline & $n=1 \rightarrow 1+3+5+7+\ldots+(2(1)-1)=1^{2}$ \\
\hline & $n=k \rightarrow 1+2+5+7+\cdots+(2 k-1)=k^{2}$ \\
\hline & - alean dibuktikan $u=k+1$ \\
\hline & $1+2+5+7+\ldots+(2(k+1)-1)=(k+1)^{2}$ \\
\hline & $1+3+5+7+\cdots+(2(k+1)-1)+2 k=(k+1)^{2}$ \\
\hline & $1+3+5+7+\ldots+(2 k+2-1)+2 k=k^{2}+2 k+2$ \\
\hline & $1+3+5+7+\ldots+2 k+2-1+2 k=k^{2}+2 k+2$ \\
\hline & $1+3+5+7+\cdots+2(k+1)-1+2 k=k^{2}+2 k+2$ \\
\hline
\end{tabular}

Gambar 2. Jawaban subjek 2

Pada Gambar 2 terlihat bahwa siswa telah memahami maksud soal dengan menggunakan jenis bukti yang benar yaitu induksi matematika melalui tiga langkah bukti, namun siswa terlihat kebingungan pada saat mengerjakan langkah ketiga ditandai dari tidak adanya simpulan karena pengerjaan matematisnya tidak selesai.

Berikut hasil petikan wawancara peneliti dengan subjek :

Peneliti : Sepertinya jawaban kamu pada langkah ketiga ini belum selesai ?

Siswa : Ya buk, saya bingung. Lupa cara buktiinnya.

Peneliti : Apakah sekarang kamu bisa mengerjakan soal ini?

Siswa : Hmm...gak bisa buk.

Berdasarkan hasil tes dan wawancara di atas dapat disimpulkan bahwa 
siswa belum melalui tahapan proses berfikir dalam menyusun bukti matematika dengan baik, dimana siswa belum menyelesaikan solusi dengan tepat.

3. Subjek Penelitian 3

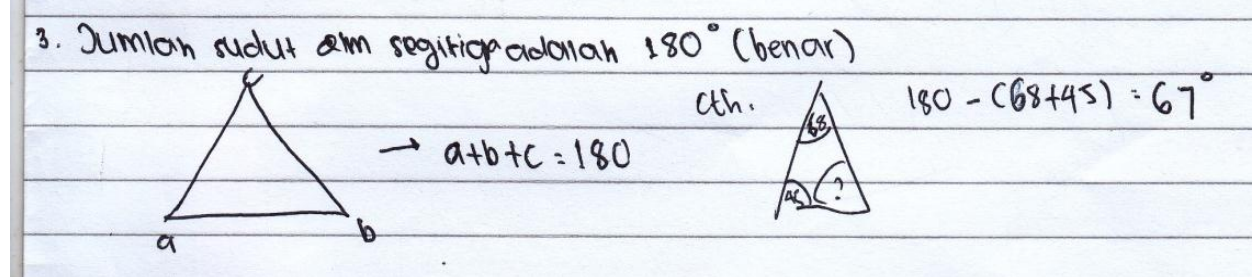

Gambar.3 Jawaban subjek 3

Pada Gambar 3 terlihat bahwa siswa belum memahami maksud soal ditandai dengan pemilihan jenis bukti yang digunakan masih keliru, dan tidak ada penyelesaian dari jawaban yang diberikannya.

Berikut hasil petikan wawancara peneliti dengan subjek :

Peneliti : Gimana cara buktiin soal seperti ini?

Subjek : Saya bingung buk, soalnya benar. Tapi saya gak tahu gimana buktiinnya.

Peneliti :Coba terangkan hasil jawabanmu!

Subjek : Itulah buk, biasanya kan enggak dibuktiin. Tapi diketahui dua sudut, habis itu disuruh cari sudut laennya. Pake aturan ini buk. Jumlah sudut dalam segitiga itu $180^{\circ}$.

Berdasarkan hasil tes dan wawancara di atas dapat disimpulkan bahwa siswa belum melalui tahapan proses berfikir dalam menyusun bukti matematika dengan baik, dimana siswa belum menyelesaikan solusi dengan tepat.

4. Subjek Penelitian 4

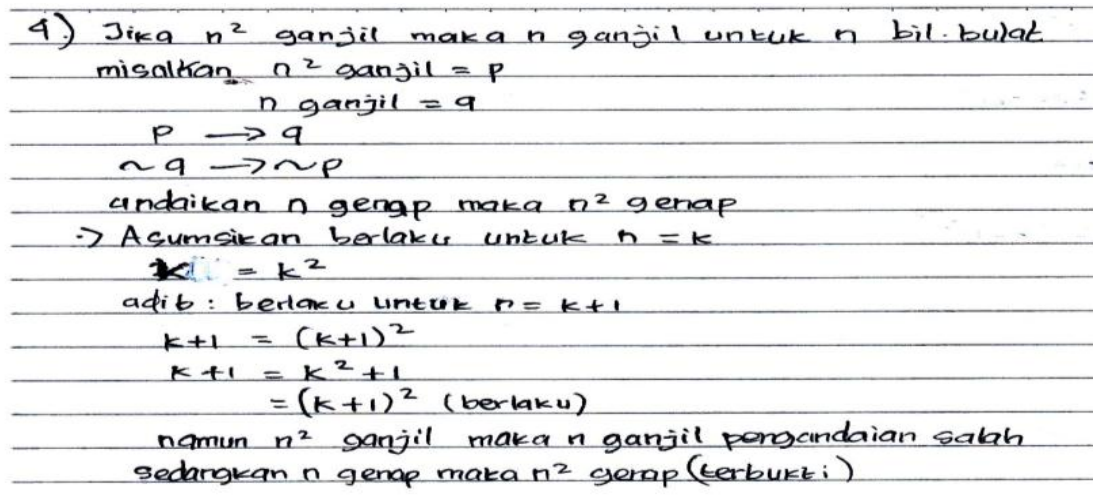

Gambar 4. Jawaban subjek 4

Pada Gambar 4 diketahui siswa keliru menggunakan jenis bukti yang tepat untuk menyelesakan soal. Siswa terlihat menggunakan bukti induksi matematika untuk menyelesaikan bukti langsung modus tollen ini. Namun, siswa mampu 
menyebutkan hipotesis yang diketahui dan konklusi yang ingin dibuktikan. Berikut hasil petikan wawancara peneliti dengan subjek :

Peneliti : Informasi apa yang diberikan pada soal?

Subjek : Diketahui n bilangan ganjil buk.

Peneliti : Lalu apa yang diminta dibuktikan pada soal ini?

Subjek : Yang mau dibuktikan $\mathrm{n}^{2}$ juga bilangan ganjil buk.

Peneliti :Terus gimana cara penyelesaiannya ?

Subjek : pakek induksi matematika buk.

Berdasarkan hasil tes dan wawancara di atas dapat disimpulkan bahwa siswa belum melalui tahapan proses berfikir dalam menyusun bukti matematika dengan baik, namun siswa telah melalui fase masuk yaitu dimana siswa mampu memahami dan mendiagnosis masalah meskipun belum mampu menyelesaikan solusi dengan tepat.

\section{Subjek Penelitian 5}

Bukti
bentuk jadi persegi panjang
Sehinga jumlah keempat sudut yg mempunyai $4 \mathrm{sisi}$
$180^{\circ}$ maka jlh sudut segitiga $10^{\circ} 0^{\circ}$
terbukti

Gambar 5. Jawaban subjek 5

Pada Gambar 5 terlihat siswa mampu memberikan simpulan yang diberikan tepat. Berikut hasil petikan wawancara peneliti dengan subjek :

Subjek : Kesimpulannya yaitu jumlah dalam segitiga $180^{\circ}$ buk.

Peneliti : Apakah kamu memeriksa kembali jawabanmu?

Subjek : Ada buk.

Peneliti : Apakah setelah kamu memeriksanya, ada jawabanmu yang berubah?

S10 : Enggak buk.

Berdasarkan hasil tes dan wawancara di atas dapat disimpulkan bahwa siswa belum melalui tahapan proses berfikir dalam menyusun bukti matematika dengan baik, dimana siswa belum menyelesaikan solusi dengan tepat.

6. Subjek Penelitian 6 


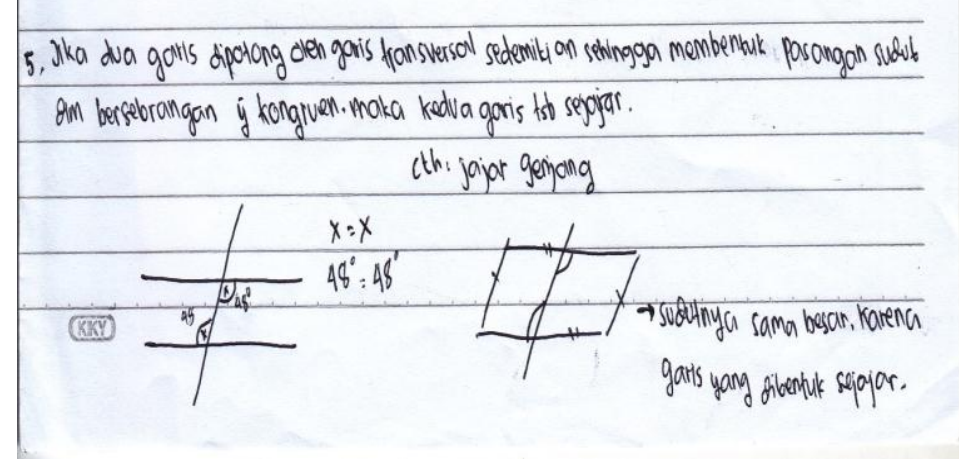

Gambar 6. Jawaban subjek 6

Pada Gambar 6 terlihat siswa memberikan simpulan yang keliru. Siswa terbalik antara hpotesis yang diketahui dan konklusi yang akan dibuktikan. Namun setelah wawancara dilakukan siswa mampu menyebutkan simpulan dengan benar.

Berikut hasil petikan wawancara peneliti dengan subjek :

Peneliti: Jadi, apa kesimpulan dari jawaban kamu?

Subjek : Kesimpulannya kedua sudut sama besar buk, eh. Kedua garis sejajar buk. Jawaban saya salah yang ini (sambil menunjukkan kesimpulan pada lembar jawabannya sendiri).

Peneliti : Apakah kamu mengecek kembali jawabanmu?

Subjek : Enggak ada buk.

Berdasarkan hasil tes dan wawancara di atas dapat disimpulkan bahwa siswa belum melalui tahapan proses berfikir dalam menyusun bukti matematika dengan baik, dimana siswa belum menyelesaikan solusi dengan tepat.

\section{Pembahasan}

Berdasarkan analisis data pada saat tes dan wawancara diketahui bahwa siswa belum melalui tahapan proses berfikir dalam menyusun bukti matematika dengan baik. Langkah bukti yang dilakukan siswa pada saat tes belum sistematis serta masih banyak melakukan kesalahan. Siswa merasa perlu banyak latihan mengerjakan soal-soal seperti ini karena soal seperti ini lebih sulit dari pada soal hitungan biasa. Hal ini sejalan dengan temuan penelitian Maya \& Sumarmo (2011: 240) yang menemukan bahwa siswa lebih kesulitan dalam mengkonstruksi bukti daripada memahami tugas matematika. Walaupun demikian siswa telah mengetahui jenis-jenis pembuktian seperti bukti langsung, tidak langsung dan induksi matematika walau terkadang ketika bertemu soal masih bingung akan mengerjakan soal dengan jenis bukti yang mana.

Berdasarkan analisis dan temuan peneliti diketahui bahwa siswa dengan kemampuan akademis yang tinggi memiliki kemampuan menyusun bukti matematis lebih baik dibandingkan siswa yang kemampuan akademisnya kurang. Hal ini didasari dari hasil jawaban tes siswa dan pada saat wawancara yaitu semua siswa yang mengikuti bimbingan tambahan diluar sekolah mampu menjawab 
semua soal tes walau masih melakukan kesalahan. Seperti halnya dengan temuan penelitian oleh Masfingatin (2014: 6) yang menemukan bahwa siswa yang memiliki kemampuan tinggi memiliki kecenderungan mampu menggunakan unsur-unsur proses berpikir secara tepat.

\section{SIMPULAN DAN SARAN Simpulan}

Proses berpikir siswa dalam menyusun bukti matematis menunjukkan: (1) empat siswa telah memahami dan mampu mendiagnosis masalah diketahui dari jawaban semua siswa yang mampu membedakan antara hipotesis dan konklusi dari tes yang diberikan untuk tiap jenis bukti, namun siswa lainnya keliru dalam menentukan jenis bukti yang tepat sehingga dapat disimpulkan sebanyak 66,67\% siswa telah melalui tahap entry phase; (2) semua siswa telah ada ide untuk melakukan langkah penyelesaian dalam menyusun bukti matematis, namun sebahagian besar masih keliru dalam langkah penyelesaiannya sehingga tidak mendapatkan solusi pembuktian yang tepat. Hal ini mengakibatkan hanya dua siswa yang melalui tahap attack phase yaitu sebanyak 33,33\%; (3) 5 siswa telah mengaitkan inti permasalahan di soal dengan penyelesaian yang dilakukannya diketahui dari jawaban siswa yang telah membuat simpulan dengan tepat dan mengecek kembali jawabannya, sehingga dapat disimpulkan sebanyak 83,33\% siswa telah melalui tahap review phase.

\section{Saran}

Saran yang perlu dipertimbangkan diantaranya adalah bagi peneliti lainnya yang ingin melakukan penelitian serupa dengan penelitian ini atau yang ingin melanjutkan penelitian ini, sebaiknya dalam melakukan wawancara dilakukan berulang kali untuk memperkuat data.

\section{DAFTAR RUJUKAN}

Katagiri, S. (2012). Mathematical Thinking and How to Teach It. Tokyo: CRICED, University of Tsukuba.

Kusnandi. (2008). Pembelajaran Matematika dengan Strategi Abduktif-Deduktif untuk Menumbuhkembangkan Kemampuan Membuktikan pada Mahasiswa. Disertasi Universitas Pendidikan Indonesia: tidak diterbitkan.

Lestari, K. E. (2015). Analisis Kemampuan Pembuktian Matematis Mahasiswa Menggunakan Pendekatan Induktif-Deduktif pada Mata Kuliah Analisis Real. Jurnal Kajian Pendidikan dan Pengajaran, 1(2), 128-135.

Masfingatin, T. (2014). Proses Berpikir Siswa Sekolah Menengah Pertama dalam Menyelesaikan Masalah Bangun Ruang Sisi Datar Berdasarkan Teori Van Hiele, Jurnal Ilmiah Pendidikan Matematika, 3,(1), 1-8.

Mason, J., Burton, L. \& Stacey, K. (2010). Thinking Mathematically Second Edition. England: Pearson Education Limited.

Maya, R. \& Sumarmo. U. (2011). Mathematical Understanding and Proving Abilities: Experiment with Undergraduate Student by Using Modified Moore Learning Approach. IndoMS Journal on Mathematics Education, $1(2), 231-250$.

Miles, M.B, Huberman,A.M, dan Saldana,J. (2014).Qualitative Data Analysis, A. Methods Sourcebook Edition 3. 
Moore, R. C. (1994). Making the Transition to Formal Proof. Educational Studies in Mathematics, 27(3), 249-266.

NCTM. (2000). Principles and Standards for School Mathematics. Virginia: Reston.

Oktaviyanthi, R., Herman, T., \& Dahlan, J.A. (2018). How Does Pre-Service Mathematics Teacher Prove The Limit of A Function by Formal Definition? Journal on Mathematics Education, 9 (2), 195-212.

Piaget, J. \& Inhelder, B. (2010). Psikologi Anak. Yogyakarta: Pustaka Pelajar.

Strauss, A., \& Colbin, J. (1997). Dasar-Dasar Penelitian Kualitatif Prosedur, Tehnik dan Teori. Surabaya: Bina Ilmu Ofset.

Tambunan, G. \& Murtadho, S. (1987). Pengajaran Matematika. Jakarta: Karunika. 